\title{
THE FAILED LIBERALISATION OF ALGERIA AND THE INTERNATIONAL CONTEXT: A LEGACY OF STABLE AUTHORITARIANISM
}

Francesco Cavatorta

Dept. Of Political Science

Trinity College Dublin

1 College Green

Dublin 2, Republic of Ireland

e-mail : cavatorf@tcd.ie

Word Count : 9,318 
The paper attempts to challenge the somewhat marginal role of international factors in the study of transitions to democracy. Theoretical and practical difficulties in proving causal mechanisms between international variables and domestic outcomes can be overcome by defining the international dimension in terms of Western dominance of world politics and by identifying Western actions towards democratising countries. The paper focuses on the case of Algeria, where international factors are key in explaining the initial process of democratisation and its following demise. In particular, the paper argues that direct Western policies, the pressures of the international system and external shocks influence the internal distribution of power and resources, which underpins the different strategies of all domestic actors. The paper concludes that analysis based purely on domestic factors cannot explain the process of democratisation and that international variables must be taken into more serious account and much more detailed.

\section{Introduction}

In recent years, the literature on transitions to democracy has begun to analyse in more detail the international context of regime change. This aspect had been labelled 'the forgotten dimension' ${ }^{1}$ due to theoretical shortcomings and practical difficulties in gathering evidence, but it is now recognised that international factors are an important component of transitions to democracy. For instance, in his analysis of transitions in Eastern Europe, Sakwa argues that 'democratisation in the region is to a large degree a function of international processes and is far from being solely an endogenous process. ${ }^{2}$ Nevertheless, explanations focusing on domestic factors and processes still dominate the literature.

The purpose of this paper is to introduce systematically international factors in the analysis of transitions by utilising the experience of Algeria in the late eighties and early nineties. These international factors include both 'systemic pressures' and specific policy actions that Western liberal democracies undertake. Western powers play a double role in this respect. On the one hand, they are often decisive in encouraging and sustaining democratisation since they all clearly set out the promotion of democracy abroad as one of their main foreign policy objectives. On the other hand, they contribute to crushing transitions when the outcome cannot be 
controlled and challenges the stability upon which they rely to extract benefits and resources from the international system. The impact of the international context is particularly strong in regional settings where profound economic, social, political and cultural differences exist; the Mediterranean basin is certainly such a region. In this area the perception of threats is greater and the fear of radical transformation is often unwelcome. The paper thus argues that the international dimension was at least partly responsible for the initiation of the democratic process and for its demise by the Algerian military.

At the same time, the paper attempts to offer an innovative analysis of the failure of the Algerian transition. The justification for the choice of case study lays in the need to explore the origins of the process of democratisation and its subsequent demise. There are studies of how the international community reacted to the intervention of the military, ${ }^{3}$ studies on how the international community could help solving the political conflict, ${ }^{4}$ examinations of France's position towards the parties in conflict $^{5}$, and works on how domestic parties attempted to influence the perceptions of external agents ${ }^{6}$, but there is the need for a careful and systematic examination of past events to provide a solid understanding of how domestic actors were influenced by and perceived their external environment. The theoretical framework and the questions arising from the case study inform each other and their dynamic relationship seems to point to the centrality of the international dimension of democratisation.

\section{The international dimension}

The relevance of the international context is evident in the events occurred in Eastern Europe and Central America and it is beyond doubt that major shifts in the 
distribution of power in the international system and global political and economic trends contributed to a number of democratisations. ${ }^{7}$ In his work, Samuel Huntington pointed out that the democratisations of the third wave have been the product of international economic and political triggers, but fails to follow up on that point and reverts back to explaining the transitional processes through domestic variables. ${ }^{8}$ Some of these international triggers such as changes in the international economy, the difficulties of socialism and the increased legitimacy of the discourse of human rights can be seen at work in Algeria as well.

Laurence Whithead attempted to capture and systematise the international dimensions of democratisation and his categories of 'contagion', 'control' and 'consent' are very useful tools of analysis, but his framework should be expanded on and detailed. ${ }^{9}$ Others built on that study and attempted to account for international factors in their comparative overviews of transitions, but found theoretical and practical obstacles. Despite these impediments, the issues related to the effect of the international context must be analysed more closely. In a global system of interdependent political and economic relations, international variables can play a key role in determining the domestic structure of countries in transition. International factors cannot simply be considered as a secondary and indirect source of influence. They have a direct impact on all aspects of democratisation, from its initiation to its consolidation or from its early difficulties to its demise. There is agreement in the literature concerning the autonomy of domestic political forces ${ }^{10}$ and the subsequent peripheral role assigned to international factors, for instance the so-called facilitating argument. This stems more from the difficulties of establishing clear-cut causal mechanisms between international variables and outcomes of democratisation rather than from theoretical assumptions or definitional difficulties. 
When it comes to discuss the changes taking place in Algeria at the turn of the eighties, it is just as important to focus on the international dimension as it is on the domestic factors. There are three specific issues that should be tackled: 1) issues of access of international actors to domestic actors and how this access is used to promote foreign policy goals that change the costs/benefits calculation of action/inaction of these domestic actors; 2) issues of indirect pressures from the international system itself such as the necessity to adopt a specific form of regime in order to be included in the international community or to fulfil a pre-determined role in the world-system. and 3) external shocks that affect the strategies of the players.

The role of Western countries is constantly underplayed, even though they have considerable power in shaping international affairs thanks to a combination of economic and military might, domination of international organisations, and political influence. Powerful countries have a much greater impact than what is generally conceded. Thus, in its most extreme form, the study of transitions could be entirely reversed and it could be argued that a structural approach would put international pressure at the core of the analysis on democratisation as it 'forces' specific domestic choices by setting an agenda of feasible options constrained by the interests of the dominating states. It could then be argued that decisions or outcomes seemingly deriving from autonomous domestic choices or factors are in reality the product of 'invisible' but strong external pressures that determine the timing and the structure of democratisation or, eventually, its demise and failure. Admittedly, this argument would fail to capture the complexities of reality, the diverse degrees and timing of the external pressure exercised, and the complicated interaction between domestic factors and 'foreign' forces. A multi-causal explanation would allow escaping from the rigidity and improbability of monocausality and, at the same time, to look for 'degrees' 
of influence that should be assigned to the different factors at play. The centrality of the international context is reinforced during the consolidation period. In fact, the role of international factors is not solely limited to the 'initiating' aspect of democratisation, but can also account for the failure of new democracies to consolidate. It is often stressed that the West plays a key role in promoting democracy and that liberal economics encourages countries to be more open and more 'penetration-prone' to the ideas and the institutions of democracy. While penetration proved beneficial in a number of cases (Spain, Portugal, Greece among others) and Western support for democratising efforts increased in the last decade, this facilitating role is 'conditional'.

The national interests of the most powerful countries shape the international political climate and the socio-economic structure of the international system. Countries embracing democracy and its institutions have thus to conform to a preconceived form of democratic structure based on the experience and the needs of Western liberal-democracies. Moreover, they have to take into consideration their prospects of integration in the international economic system with all the constraints that derive from it. If the West shapes the international system according to its interests, it follows that those who will conform will be rewarded and those who do not will be punished. Democracy and democratisation then become foreign policy tools utilised to pursue interests. It is so much so that 'the noble concept, 'democracy', has become, along with universal suffrage, just another rhetorical device. ${ }^{11}$ Western liberal-democracy is deemed to be working when its institutions, properly transplanted in a democratising country, lead to the outcomes expected in the West. These outcomes consist of political stability, free-market economic reforms, some sort of allegiance to Western ideals, and loose respect for basic democratic procedures 
and liberal rights. When instead the outcome of the transition is likely to lead in directions opposed by the West, pressure is exercised to force a change. This pressure may or may not lead to the desired outcome, but it is designed to obtain results. Achieving stability and security is then the primary objective and this is obtained with the help of domestic forces afraid to lose out from the regime change and that, once in control, will be a more reliable interlocutor for the West. For instance in the Algeria case, where Franco-Algerian relationships are 'far from being traditional political relations between nation-states, but are about economic co-operation and political networking. ${ }^{12}$, the replacement of the elites in power would have led to a problematic re-negotiation of these links. Thus 'democracy' is a concept that can be bent to fit Western interests and international patterns of political and economic development. Algeria might just be another country in the line of 'undesirable' democracies that disturbed the smooth running of the liberal international order. It is hotly debated whether Algeria's democratisation was a 'true' one, but it seems that if the definition of procedural democracy is adopted, the Algerian transition fulfils the criteria. Transitions are understood mainly in terms of regime change towards a Western-style liberal democracy with a strong emphasis on procedural aspects. Despite difficulties and obstacles, Algeria was labouring its way to adopt and work within such a system.

International variables should obviously not obscure the role and interests of internal actors. In particular, the distribution of power and resources among domestic actors together with their objectives is relevant to the entire process and should not be relegated to a marginal role. However, it should be underlined that the very distribution of resources within the domestic sphere is influenced by outside pressure that can determine who will be the beneficiary of specific resources provided by external actors or generated by systemic forces. The Algerian case offers, among 
others, the issue of military intervention in a democratic election. It is accepted that the decision to intervene was a purely internal affair, but the costs of intervention may have been lowered or increased by previous knowledge of the international reactions to it. If the international environment is perceived to be supportive of the intervention, the costs of carrying it out largely diminish. The external element becomes a relevant factor in the decision-making process. Established liberal democracies have an interest in promoting democracy around the world and they are seen as potential facilitators because they can exercise a considerable amount of pressure against recalcitrant authoritarian rulers. Unfortunately, such a strategy of rightful 'promotion' is undermined by the lack of a standardised conceptualisation and application of democratic principles. Western policies concerning the promotion and defence of democratic principles and values are flawed because they are adapted to national interests. Democratic principles are sometimes in conflict with much more compelling interests (security, gaining access to markets and resources, protecting investments) and the resulting overall foreign policy is the product of these 'internal struggles' among competing interests. ${ }^{13}$ From this, it follows that the lack of 'a clear and consistent standard of what democracy entails on the part of countries seeking to nurture democracy ${ }^{14}$ undermines Western credibility, democracy's appeal, and ultimately favours authoritarian rulers who will search for democratic legitimisation to please international institutions and foreign investors, without really allowing for a meaningful opening of the political space.

If this theoretical structure of transition concerning the international context holds, the analysis of this complex phenomenon will be easier. Differences between countries who succeeded and those who did not could then probably be connected to 'international variables'. The utilisation of such theoretical framework for countries on 
the Southern bank of the Mediterranean could lead to understand the reasons why effective democratic rule is not a feature of North African political systems.

\section{The case of Algeria}

In Algeria, external factors impacted, at varying degrees, on the initiation, development and failure of the transition. The influence of two different 'international effects' and their convergence with the interests of key domestic actors led first to a process of extensive liberalisation and then to the dismantling of the democratic process through a military intervention. These three effects are: a) 'systemic pressures', which force countries in the process of democratising to conform to specific political and economic requirements in order to fit in a West-dominated system, b) 'ad hoc policies' adopted by France, the United States and, to a lesser extent, other European countries aimed at influencing the distribution of power among internal actors in order to arrive at their most preferred outcome; and 3) external shocks and events that conditioned the domestic bargaining game, changed the structure of incentives and modified the strategies of the different actors.

The relevance of the international dimension should not obscure the existence of different explanations that have been offered for the failed democratisation of Algeria. Specifically: a) the inherent incompatibility between Islamic culture and democracy ${ }^{15}$; b) the interests of key domestic actors, particularly the Army, in going forward with democratisation and then changing the course of the process ${ }^{16}$; and c) the failure of economic liberal reforms. The first explanation is certainly powerful, but it can be countered by arguing that any 'culture' is able to develop a democratic spirit and lead to the installation of democratic institutions. For instance, there are a number of schools of thought within the Islamic world that do not see any 
incompatibility between Islam and democracy and actually call on the current generation of Muslim leaders to implement democratic reforms. ${ }^{17}$ It could be argued that, in fact, any serious attempt to democratise a country where Islam is the dominant religion failed not so much because Islam is incapable of dealing with democratic principles per se, but for the opposition of the governing elites which found very comfortable the idea of an inherent conflict between Islam and democracy in order to hold on to their privileges with the blessing of Western powers.

The second explanation, focusing on actors and their rational strategic choices, is somewhat incomplete. While it is true that intra-elites power struggles and bargaining processes are key to any explanation, external agents and external developments affect the internal distribution of power and resources. Explanations focusing exclusively on the dealing among domestic actors run the risk of looking at the transition as if it was occurring in a political vacuum, in complete isolation from the international system.

The belief that the transition failed due to the failure of liberal economic reforms does not capture the complexity of the reform process. The IMF-sponsored liberal economic reforms, far from sparking demands from a new class of businessmen for political change, had the opposite effect of allowing the regime to tighten the grip on society and derail change. Sections of civil society normally associated with demands for greater political liberalisation become in fact the main supporters of the continuation of the existing political order. The reforms of the mid1980s simply created a class of nouveaux riches, who enriched themselves thanks to their connection with powerful figures. Thus, 'businessmen, instead of becoming vigorous proponents of free markets, end up as crony capitalists, making profits because of their connections to those in power. ${ }^{18}$ 
The contribution of previous explanations suggests that we should not underestimate the role of domestic actors or the strategic choices or cultural and historical aspects peculiar to Algeria. There is nevertheless a strong argument for the possibility that external factors did influence the transition. Assuming that internal factors are all explaining would be pretentious and theoretically difficult to defend.

The origin of Algerian transition is held to be the October 1988 riots. The harsh crackdown signified the beginning of the end for the ruling the Front de Liberation National (FLN). The riots were rooted in economic distress but were also a sign of a more profound malaise in Algerian society, which had been subjected for too long to authoritarian rule. Surprisingly, the regime responded to the crisis by opening up the political system and gave way 'to a new era of pluralistic competition. 19

President Chadli and the Army hoped that multi-party competition and freedom would lead to renewed legitimacy and their political survival. Thus, it would appear that the initiation of democracy and its demise could be simply understood in terms of domestic pressures and strategic choices of the principal actors. ${ }^{20}$ However, the October riots were not rooted only in the domestic sphere. First of all, economic hardships depended greatly on pressures deriving from the international economic system and were not only a consequence of mismanagement of resources and corruption. In particular, the price of oil and gas, on which Algeria relied to sustain its internal market and generous welfare state, had fallen sharply over the last few years 'from $\$ 13.5$ billion in 1985 to $\$ 9.6$ billion in 1986 and $1987 .{ }^{21}$ The sharp drop in oil and gas revenues is the external shock that exposed the structural weakness of the Algerian economy and further undermined the fate of the market-oriented reforms of the previous years. The 1985 and 1986 counter-shocks were the trigger of the crisis, which the IMF-sponsored reforms aggravated. These reforms had been carried out by 
a small group of economists within the Algerian government in collaboration with IMF officials, even though there was no formal agreement between the IMF and the Algerian government at the time. The pressure to conform to a new international economic order was on. These IMF-sponsored reforms and the drop in revenues had in turn dramatic consequences on the general well being of the population. ${ }^{22}$

On the political front, the socialist ideology was under intense criticism worldwide thanks to the failings of the socialist bloc and the imminent Western victory in the Cold War led to a profound rethinking within the Algerian ruling elite. The pace of the political changes, initiated with the introduction of the new constitution in February 1989, accelerated in the following years. The collapse of the Soviet empire has been interpreted as a major ideological victory for Western liberal democracies with their emphasis on individual rights, formal democratic procedures and free market economy. In this rapidly changing international environment, where Western countries were both victorious and confident of their superior system of government, Algeria had to adapt its domestic political and economic institutions in order to survive and benefit from the changes that had taken place. The realisation that only Western recognition and support would be 'the only game in town' convinced the elite to become 'liberal democrats', but their credibility was very shaken by the opportunism they showed. On the contrary, the FIS played on its credibility and revolutionary purity to further its support. In this new competition for control, Chadli believed that democratic politics would turn the Algerians away from the FLN and steer them toward him. Chadli's calculations backfired when it became clear that the FIS had capitalised on the legitimacy's crisis of the regime.

The democratisation process was at first welcomed and encouraged in the West. The Islamic Front was not yet considered a threat and the USA, traditionally 
close to a number of radical Islamic movements, were not opposed to the FIS as a matter of principle like some of its European allies. ${ }^{23}$ Moreover, Western diplomats and observers expected that the new multi-party system would lead to the formation of a coalition government which would have resulted in political moderation, institution building, and the steady continuation of economic reforms. Chadli and the Army also probably expected power-sharing to be the outcome and this could explain why they did not take over power before January 1992. The June 1990 local elections had given a stunning victory to the FIS $^{24}$, but Chadli was still hopeful that he could work out a deal to force the FIS into sharing government responsibilities. The electoral results however convinced the French and their European allies that the process of democratisation was favouring anti-Western forces.

The Gulf War further affected the development of the transition. The Algerian government condemned the invasion of Kuwait, but worked immediately to avoid an internationalisation of the crisis that would likely lead to war and major divisions among Arab states. $^{25}$ During the military operations themselves, the Algerian government progressively hardened its stance against the West, but failed to convince the population of its real opposition to the war by not taking any measure susceptible to interpretation in the West as pro-Saddam. This fine balancing act failed to work, as the Algerian population and opposition movements increasingly criticised western countries. What is very important for the Algerian transition is that the Gulf War 'considerably inflamed the passions within which Algerian politics took place ${ }^{26}$ and was the external shock that began to destabilise a certain equilibrium and peaceful coexistence that had been reached between the FIS and the elite in power. Both Leveau and Labat point out that the Gulf War unsettled the informal and unofficial pact of non-aggression between the FIS and the Chadli presidency and undermined the 
possibility of a smooth transition by radicalising both sides. ${ }^{27}$ The Gulf War affected the strategies and perceptions of three key core actors in the transition.

The leadership of the FIS was at first at odds on how to react to the Iraqi invasion of Kuwait and the Saudi response to it. The FIS had been receiving funds from Saudi Arabia to carry out its political and social activities and it was reluctant to fully support Saddam Hussein in his enterprise. However, given the popular mood, the FIS quickly found itself at the helm of street demonstrations that were clearly proSaddam and anti-Western. The strong popular and spontaneous support for Saddam encouraged the FIS to be more adventurous and the leadership 'canalised and exploited the urban masses' dissatisfaction by ditching their previous prudent stance. ${ }^{28}$ The FIS saw the Gulf War as a major boost to its position within an Algerian society that found itself deeply at odds with Western actions. FIS actions were not simply limited to mass demonstrations challenging the Algerian government to take radical actions against the West, but went as far as trying to send volunteers to fight with Saddam troops and to request officially that the government 'stop exporting oil and gas to those countries involved in the aggression against Iraq. ${ }^{29}$

From the point of view of the government, the Gulf War presented the opportunity to play a relevant role in negotiating a solution that would see Algeria becoming again a central actor in international politics. Algeria was looking to reinvent itself in the New World Order after having abandoned its key role of mediator between the Eastern bloc and the movement of non-aligned countries. A peaceful outcome of the crisis obtained thanks to the efforts of the Algerian diplomacy would have increased the international prestige of the President and would have made Algeria a privileged interlocutor of the West with the Arab world. Unfortunately for the regime, this policy backfired. As previously underlined, the 
population was largely pro-Saddam and the government tried to harden its stance against the US-led coalition, but was sidestepped by the much more radical FIS discourse. The government was caught between the need to be seen by the West as a reliable partner and the need to be seen as voicing the worries of the majority of the population. This dilemma was not solved and 'the Gulf crisis revealed the cruel delegitimisation of the Chadli government, ended the political apathy of the population and marked the end of the government foreign policy aimed at reinserting Algeria in the international system. ${ }^{30}$ The problems of the governing elite were compounded by the fact that, while trying to normalise relations with France, they were open of being accused to colluding with the 'enemy', as France had chosen to stand side by side the United States to the detriment of its privileged relations with North African countries.

The Gulf War and the reactions it provoked in the Arab world began to dominate also the Western agenda. Concerning the situation in Algeria, the French government was finally convinced that the arrival to power of the Islamic Front would be detrimental to French interests and security. According to a presidential aid ${ }^{31}$, the French government had already tremendous reservations about the FIS, not so much for its dubious democratic commitment, but for the anti-France policies it might implement. The Gulf War dispelled eventual reservations. Before the outbreak of hostilities against Iraq, President Mitterrand was quite confident that relations with North African countries would not be affected by French participation in the war against Iraq. ${ }^{32}$ His conviction and confidence were quickly put to the test and the events of the following months seemed to confirm to many in France the dangers that the FIS would pose. ${ }^{33}$ In July 1991 the magazine Jeune Afrique published a detailed 
article highlighting the French position on political developments in the Maghreb with the title 'Mitterrand against the Islamists'. ${ }^{34}$

However, and more importantly, the Gulf War had the effect of changing American perceptions of its interests in Algeria. Changes in policy followed swiftly. The United States had traditionally had poor relations with their Algerian counterparts due to the commitment of Algeria to anti-imperialism and third-worldism. Moreover, Algeria had privileged military relations with the Soviet Union $^{35}$ and this was not well perceived in Washington even if the US were an important commercial partner for Algeria. For these reasons, the United States did not share the French preoccupation about the FIS. The commitment of the FIS to liberal economics and the opportunities that American companies might exploit in the region placed the United States ahead of European countries given the strong anti-French sentiments within the FIS. In addition, the fear that Algeria might follow the path of revolutionary Iran drove the United States diplomacy to entertain relations with FIS representatives. American policy-makers were still haunted by the mistakes committed during the Carter administration when clinging to the Shah alienated them from the new revolutionary actors emerging on the Iranian scene. Given that the United States traditionally had good relations with some fundamentalist movements, ${ }^{36}$ US policy-makers believed that they could 'do business' with the FIS as well.

For American diplomacy, 'the only real preoccupation is the stability of Arab and Muslim countries and not the type of regime in charge, particularly if they are sitting on billions of cube metres of gas like Algeria. ${ }^{37}$ This is, effectively, the bottom line of American policy-making in the region and the ambiguity towards the FIS present in American policies since the creation of that party disappeared during the Gulf War. The Gulf crisis showed to American policy makers that the FIS would 
challenge the given international order and, more generally, 'it reminded both the US and France the political and strategic importance of Algeria. ${ }^{, 38}$ The FIS was poised to win the parliamentary elections to be held later in the year and Western governments, already worried about the future of their economic ties to Algeria, felt threatened. It follows that, even in times when the promotion of democracy was at the top of the foreign policy agenda in western countries, 'the hostile attitude of the FIS during Desert Storm contributes to explaining the moderate reaction of the United States to the cancellation of the parliamentary elections in January 1992. ${ }^{39}$

Given that 'stability' is the true interest of the United States in the region, it follows that the exiting Bush administration did not sanction the military coup on the grounds that it had been carried out according to constitutional procedures. The Bush administration was severely criticised from members of the democratic opposition for its lack of resolve in condemning the cancellation of the elections and for its 'inconsistencies' and double standards. ${ }^{40}$ The question was asked how could the President defend the institutions and procedures of democracy in Eastern Europe and Latin America, but not in Algeria. Ahmad Moussali goes even further and argues that 'Washington has also welcomed the Algerian government's iron-fist policies towards the Islamists and its suspension of the elections. ${ }^{41}$

After being postponed for a few months, the general elections were finally held in December 1991. The FIS won a landslide victory, but the Army carried out its coup. The international community was not displeased with the Army intervention. There are a number of intertwining interests and pressures that can account for the failure of Algeria to keep the course of democratisation. At the time of the 1990 local elections it was widely believed in European capitals that the rise to power of the Islamic Front in Algeria would have certainly posed serious concerns to the West in a 
number of fields: military security, economic relations, migration, 'ideological confrontation', and stability in the Middle East. Given Algeria's position in the Mediterranean, NATO and France's southern flank could be exposed to a serious military threat even if the Algerian military had limited conventional capabilities. What concerned France and the NATO countries was in fact Algeria's nuclear $\operatorname{program}^{42}$. It was believed, or at least made believe, that Algeria was capable of acquiring nuclear capabilities and a nuclear bomb in the hands of an Islamic party was considered an unacceptable risk. Thus, an anti-Western government in power next to the borders of France, Italy and Spain could not have been welcomed.

An Islamic government in Algeria could have had also a destabilising impact on Tunisia, Morocco and Egypt where there are active opposition Islamic groups. These might have been encouraged and supported by a democratically elected FIS-led government in Algeria, leading therefore to a South-South conflict scenario. As noted by Abed Charef, 'both the Americans and the French were equally uneasy about the fate of their allies in the region, Tunisia and Morocco. ${ }^{43}$ Heavily destabilised areas would have then surrounded Europe, with the contemporaneous breakout of chaos in the Balkans and in the Maghreb. International repercussions could have also been felt in the Middle East where the Israeli and Palestinians had just begun to work out a peace-agreement, to which the FIS was opposed. On the contrary, the Algerian military was more supportive of the agreement and saw it as a chance to improve relations with the West in the key area of military links, having Algeria lost the support of the Soviet Union.

The state of economic relations was also at stake. Western investments and energy supplies could have been threatened. ${ }^{44}$ The FIS never clarified the specific economic measures it would introduce once in power. These very vague 
commitments meant that a dangerous uncertainty regarding protection of foreign investments in the very lucrative gas and oil sector surrounded the FIS economic programme. While 'the FIS industrial programme ends with a call for more involvement of the private sector, it also clearly assigns a central role to the state ${ }^{, 45}$, particularly in key sectors of the economy. It follows that a general commitment to market economy did not automatically translate into further Western investments, protection of Western interests, or the continuation and implementation of existing contracts. In addition, Aliboni argues that 'a radical regime is more easily tempted to set political considerations above the reality of oil transactions ${ }^{46}$. While this point may be disputed, it certainly rings bells in policy-making circles. The Army would be able to guarantee 'economic' stability and protection much more effectively than the FIS.

In addition, with the FIS in power there would have been tremendous changes in the personnel involved with state economic activities as the FIS had promised to get rid of the corrupted bureaucrats and managers working in the state sector. A younger generation of educated and current unemployed Arab-speaking technocrats supportive of FIS might have replaced them. The state apparatus was the executioner of military and political decisions, but was also 'a vast network of personnel, bureaucrats, and public sector entrepreneurs maintaining a symbiotic relationship with the regime, carrying out its dictates in return for personal profit. ${ }^{47}$ Market oriented reforms had given them the means for personal enrichment and corruption grew out of control, particularly in the oil sector. This took place to the detriment of a class of new technocrats who turned to FIS to channel their discontent and who, once in control, might have had different ideas regarding the on-going economic policies. 
Another aspect to take into consideration is migration. A FIS government, it was believed, would have meant a huge influx of immigrants into Southern Europe as people afraid of the instauration of an Islamic Republic might have wished to leave the country. There was a feeling that many would flee Algeria and join relatives or friends in France and to a lesser extent other southern European countries. Public opinion in those countries would have not easily tolerated a wave of Algerian refugees. The French and Italian governments felt that this aspect of Mediterranean relations could have been better served with a strong, efficient military junta.

James Phillips, a senior policy analyst at The Heritage Foundation in Washington DC, summarised briefly American interests in the area: 1) maintain support for Pro-Western Arab secular regimes; 2) contain international terrorism; 3) defend the peace process between Israel and the PLO; 4) increase non-proliferation efforts; 5) keep a safe access for the West to the energy resources in the area and 6) defend human rights. ${ }^{48}$ These interests, he argued, would have been best defended if the Army remained in control in Algeria. For these reasons the West turned a blind eye on the dismissal of democracy in Algeria and 'favoured' the Army's coup. Naturally, the military intervention would not have taken place without the convergence of domestic interests. Key players within the FLN, the Army and the bureaucracy did not want the FIS in power because their privileges would have been endangered. Others were truly worried about the possibility of having to live in an Iranian-style Islamic Republic. The Army perceived the FIS as a threat to national unity and to the status of the Army itself within Algerian society.

Fear of fundamentalism was probably misplaced, as a number of studies on the FIS do not seem to point in that direction. The FIS was more a social movement with religious connotations rather than a fundamentalist party with a coherent 
political programme and ideological commitments. While Islamic traits are an important component of the FIS policies, these are more concerned with social issues. According to Hugh Roberts, 'Algerian Islamism during this period (early 1990s) was never subversive or revolutionary. ${ }^{49}$ Redistribution of wealth, end of corruption, equal access to state jobs, end of discrimination for non-French speakers, promotions in the civil service according to merit and not to connections were the pillars of the FIS political programme. Dissenting voices argued that FIS was not committed to democracy and Yahia Zoubir underlines that 'FIS activities and the discourse of its main leaders revealed the aversion of the party to democratic principles. ${ }^{50}$ Despite these conflicting views about the FIS nature, a campaign of demonisation of its leaders and policies occurred. When it became clear that the West was involved in this process of demonisation for its own interests, an alliance between ruling elites and Western governments was formed at the expenses of the FIS and of democratic procedures and principles. This alliance was never 'publicised' as the regime could not be seen to be too close to the 'old enemy', but it can be argued that close contacts at top level were necessary to achieve post-coup legitimacy. On the grounds of antifundamentalism it would have been much easier to justify repression and the Army argued that 'elections should not serve the purposes of a party that threatened democracy [even if] there was never a strong hint that once in power the FIS would violently impose Islamic law and radically change society, economy, and state. ${ }^{51}$ In addition 'most international and regional actors have vested interests in pushing away fundamentalists from any legitimate role in internal, regional and international affairs. $^{52}$

From an analytical point of view there are two instruments to rely on if a causal mechanism is to be established between the failed democratisation and 
international factors in the case of Algeria: 1) analyse the behaviour of international actors before the coup and 2) identify what the Algerian Army received from the West after their intervention. Concerning the first 'instrument' it is crucial to highlight the attitudes of France, the USA and the EU toward the changes taking place in Algeria in the 1980 's and early 1990 's. Franco-Algerian relations cannot be discussed in detail due to the complexity of such a relationship. It suffices to say that President Mitterrand welcomed the process of democratisation, but quickly reverted to realist politics when made aware that the opening up of the political process could mean an Islamic success. According to Martin Stone, for some time before the coup the French government had 'become increasingly concerned for the security of French commercial interests and wanted to prevent further serious instability ${ }^{, 53}$ in the migratory process in particular. Moreover, 'the French government was anxious to discourage the creation of an Islamic state and merely paid lip-service to the idea of genuine political pluralism in Algeria. ${ }^{54}$ These fears resulted in the granting of credits and loans on the part of international financial institutions ${ }^{55}$ and on the French Treasury at the end of $1989^{56}$. It must be underlined that the Chadli government played on these French preoccupations to secure favourable financial treatment, but Paris was truly committed to avoid the creation of an Islamic republic in Algeria. Disaster-like scenarios were imagined ${ }^{57}$, where hordes of boat people would try to reach Europe by sea and therefore destabilise the entire Mediterranean. Finally, Mitterrand mildly criticised the Algerian military for their intervention in the electoral process, but soon after that, 'French support for the regime became once again explicit. ${ }^{58}$

US-Algerian relationships had begun to take a positive turn in the 1980 's, after many years of mutual distrust. Chadli's economic reforms attracted interest in the 
United States and economic ties improved. American companies invested heavily in Algeria, particularly in the oil and gas sector. The US quickly became a major customer for Algerian gas. In the difficult transition years, the US were supportive of Algeria's pluralist effort, but as soon as it became clear that the FIS would become a potentially adversarial political actor, the policy changed. While American foreign policy was never openly supportive of the regime as French foreign policy until 1995, it was clear that Washington preferred the generals to the Islamists. Channels for American influence on domestic actors had been opened in 1985, as 'the United States Department of Defence had provided a small annual grant under the International Military Education and Training Program to provide professional military development courses and technical training for Algerian officers in leadership positions or deemed to be potential leaders. ${ }^{, 59}$ It is interesting to note that 'the White House first stated that the military intervention fell within the provisions of the 1989 Constitution. ${ }^{60}$ While another statement calling for respect of international democratic standards was issued later, the Administration lenient stance on a military coup at the height of a wave of democratisations around the globe was very telling about US priorities in the area. For the US, 'the only preoccupation is the stability of the Arab and Muslim countries without regards for who is in power ${ }^{, 61}$ and when it became clear that the FIS would be confrontational towards the West, differences with France were largely tactical not strategic.

Concerning the EU position toward Algeria, the EU countries delegated most of its 'foreign policy' to France. However, some EU countries were involved in bilateral relations with Algeria. The UK was very active in supporting its oil companies in Algeria and in providing the regime with new weaponry, such as two tank-landing ships in the early 1980s. In addition, the British undertook a joint project 
with the Algerian navy for the delivery of twelve fast-attack crafts armed with Italian Otomat missiles. The Italian government was also involved in sustaining the Algerian government by granting credits for US $\$ 7 \mathrm{~b}$ after the gas company SNAM was allowed to sign a lucrative contract with Sonatrach in December $1990 .^{62}$

To conclude, France, the USA, and to a lesser degree other Western countries had all access to key domestic actors, had interests to defend and therefore had a considerable impact in making Western preferences known and taken into consideration. As underlined by Habib Souaidia, 'the links between the Algerian generals and France are numerous and old. ${ }^{63}$

The second instrument through which it is possible to 'measure' the contribution of the international dimension is the 'rewards' that have been granted to the Algerian regime after the coup. The overall policy of the West was certainly to offer economic aid and political support ${ }^{64}$. This has been largely recognised in the literature on Western-Algerian relations. The new government was granted complete legitimacy by all international institutions and Western governments. After the coup, Algeria was admitted to all Euro-Mediterranean partnership initiatives. There was no strong political condemnation, there were no talks of economic sanctions, and there was not much bad press as the blame for the civil war was put on FIS. ${ }^{65}$

Secondly, France quickly supplied the regime with new weaponry, provided intelligence and exported the latest surveillance technology to be used against the Islamic movement. ${ }^{66}$ The Army's budget is difficult to quantify, but the high intensity of the conflict suggests that spending on weaponry increased from an already high figure in $1990{ }^{67}$ The data collected by the Stockholm Peace Research Institute show that military expenditure as percentage of the GDP increased constantly since 1991 and military spending went from US \$ 622m in 1991 to US \$1,119m just two years 
later. ${ }^{68}$ Justification for this support was also due to the 'externalisation' of the civil war, whereby Iran and Sudan were accused by the Algerian regime of propping up the Islamic groups. In turn, the West was able to argue that their support for the Algerian military coincided with their desire to keep international terrorism in check. Just recently, 'Qatar has ordered 7.5 million dollars worth of military equipment from Britain as a gift for the Algerian army ${ }^{69}$ with the full knowledge of the British government. In fact, Qatar Foreign Minister declared 'the British government has no objection to the export of arms to Algeria. ${ }^{.70}$

In the economic sphere, Algeria was granted a debt-rescheduling program by the IMF on two occasions. Lucile Provost highlights that both times 'the rescheduling was obtained thanks to the intense lobbying carried out by the French authorities, ${ }^{, 71}$ and the good offices of the United States. According to Martinez, both debt rescheduling and international aid allowed the regime to pay for the costs of its survival and consolidation. ${ }^{72}$ In exchange, the Algerian government accelerated the pace of IMF-sponsored reforms. The regime has also been supplied with agricultural commodities and it has benefited from a dramatic increase in foreign investments. American companies 'have more than 2 billion dollars invested in the country ${ }^{\text {,7 }}$ and French and Italian companies invested heavily as well despite terrorist threats against foreign citizens and the killings of many of them. The financial difficulties of the regime could have been exploited to pressurise those in power in accepting a negotiated resolution, but the regime was instead bailed out. The pressure might have not worked, but the simple effort would have shown ethical commitment.

According to John Entelis, 'France's position has been to stand back and allow the military government since 1992 to consolidate power, ${ }^{74}$ while the Algerian Army decided to do so to polish its image and to gain international respectability. However, 
elections exclude FIS and are rigged, as the latest presidential election demonstrated. ${ }^{75}$ The Algerian government pays lip-service to Arab nationalism and sometimes speaks against Western domination of world affairs, while negotiating and bargaining behind the scenes with the former colonial power on how to get rid of the Islamic movement and how to proceed with Algeria's economic integration in the world economy.

\section{Conclusion}

It is difficult to clearly specify the causal mechanisms that link international variables and democratisation. However, regime changes do not take place in a vacuum and international factors, in the least, influence the strategies of the domestic actors involved. External shocks, systemic pressures and international strategic considerations are just as important in initiating or shattering transitions as domestic factors. The questions arising from the Algerian experience feed into and are evidence of the relevance of the international context of regime changes. In particular, the role of Western powers cannot be dismissed as secondary, because Western liberal democracies have the means and the power to influence what takes place in the rest of the world. Moreover, the international system constrains countries in transition in adopting domestic structures that favour integration in the system otherwise they may pay the price of exclusion. Taking international factors into account is not to obscure the importance of domestic factors and point simply to structural causes, but to integrate it in order to achieve a more comprehensive explanation.

The negative legacy of events that took place a decade ago is still evident today. In January 2001 the EU granted Algeria an aid of 8 million euros to fight terrorism without strings attached (no mention of democratisation or respect for 
human rights) and despite solid evidence pointing to Army's unjustified brutality and repressive policies. ${ }^{76}$ The hopes of the late 1980 's for a progressive inclusion within the democratic camp of North African countries have been dashed, but their inclusion within the international economy has been achieved. A legacy of authoritarian rule is what we have to contend today.

1 G. Pridham, 'Democratic transition and the international environment' in G. Pridham (ed.), Transitions to Democracy (Dartmouth: Aldershot 1995) p. 445.

2 R. Sakwa, 'Introduction. The Democratic Experience' in R. Sakwa (ed.), The Experience of Democratisation in Eastern Europe (London: Macmillan Press 1999) p. 3.

${ }^{3}$ See Y. Zoubir and Y. Bouandel, 'Islamism and the Algerian Political Crisis: International Responses', Cambridge Review of International Affairs 11/2, (Spring 1998) pp. 117-133; and C. Spencer, 'Algeria: a New European Approach?' published on line: http://www.waac.org/rep98/aneweuropeanapproach.htm.

${ }^{4}$ P. Rich, 'The Algerian Crisis and the Failure of International Mediation', Cambridge Review of International Affairs 11/2, (Spring 1998) pp. 134-151.

${ }^{5}$ H. Roberts, 'Algeria's ruinous impasse and the honourable way out', International Affairs $71 / 2$, (1995) pp. 247-267.

${ }^{6}$ H. Roberts, 'The International Gallery and the Extravasation of Factional Conflict in Algeria', Cambridge Review of International Affairs 12/1, (Summer/Fall 1998) pp. 209-246.

${ }^{7}$ This point is made by G. Pridham, The Dynamics of Democratisation (London: Continuum 2000), pp. 285-314.

${ }^{8}$ S. Huntington, The Third Wave. Democratization in the Late Twentieth Century (Norman: University of Oklahoma Press 1991).

${ }^{9}$ L. Whitehead, 'Three International Dimensions of Democratization' in L. Whitehead (ed.), The International Dimensions of Democratization (New York: Oxford University Press 1996) pp. 3-25.

${ }^{10}$ One of the best works of this kind on Algeria is probably G. Hidouci, L'Algérie: la libération inachevée (Paris: La Découverte 1995).

11 J. Pilger, Hidden Agendas (London: Vintage 1998) p. 8.

12 Interview with Djallal Malti, November 15th, 2001.

${ }^{13} \mathrm{~F}$, Cavatorta, 'Geopolitical challenges to the success of democracy in North Africa: Algeria, Tunisia and Morocco', Democratization 8/4 (Winter 2001) pp. 175-194..

14 J. D. Barkan, 'Can established democracies nurture democracies abroad? Lessons from Africa' in Alexis Hadenius (ed.), Democracy's Victory and Crisis (Cambridge: Cambridge University Press 1997) p. 388.

${ }^{15}$ E. Shirley, 'Is Iran's Present Algeria's Future?', Foreign Affairs 74/3 (May-June 1995) pp. 28-44; B. Lewis, 'The Roots of Muslim Rage', The Atlantic Monthly 266/3, pp. 47-60; and B. Lewis, 'The Revolt of Islam', The New Yorker (Nov. 19, 2001) pp. 50-63.

${ }^{16}$ M. Salah Tahi explains how the Army intervened to break the democratic constitution in order to defend their interests/privileges. M. Salah Tahi, 'Algeria's democratisation process: a frustrated hope', Third World Quarterly 16/2 (1995) pp. 197-220.

${ }^{17}$ J. Esposito, The Islamic Threat: Myth or Reality (New York: Oxford University Press 1999).

18 W. Quandt, Between Ballots and Bullets. Algeria's Transition from Authoritarianism, (Washington D.C.: Brookings Institution Press 1998) p. 120.

${ }^{19}$ R. Mortimer, 'Islam and multiparty politics in Algeria', The Middle East Journal, 45/4 (Autumn 199) p. 590.

${ }^{20}$ Quandt (note 18).

${ }^{21}$ I. Khennas and M. Mekideche, 'Les hydrocarbures en Algérie: politiques internes et rapport avec le marché mondial' in M. Verlet (ed.), Coopérer avec l'Algérie: convergences et solidarités (Paris: Publisud, 1995) p. 56. 
${ }^{22}$ The effects of Chadli's economic reforms are thoroughly detailed in J. Entelis and L. Arone, 'Algeria in turmoil: Islam, democracy, and the state', Middle East Policy 1/2 (1992), pp. 24-26. For a more general outlook on IMF-sponsored reforms in the region in the late 1980s, see Y. Gazzo, 'Les économies arabes face à la crise', Maghreb-Machrek No. 120 (Avril-Juin 1988) pp. 58-67; J. P. Sereni, 'L'Algérie, le FMI et le FIS', Les Cahiers de l'Orient, 25-26 (Prémier et Deuxiéme Trimetsre, 1992); and A. Lamchichi, Le Maghreb face à l'Islamisme (Paris: L'Harmattan 1997).

${ }^{23}$ For a detailed analysis see P.M. de La Gorce, 'L'Algérie et les Grandes Puissances', Recherches Internationales 43-44 (Hiver-Printemps 1996) pp. 21-41.

${ }^{24}$ The tables with the results and exact percentages of the June 1990 local elections can be found in A. Pierre and W. Quandt, The Algerian crisis: policy options for the West (Washington DC: Carnegie Endowment for International Peace 1996) p. 65.

${ }^{25}$ N. Grimaud, 'Prolongements externes des elections algériennes', Les Cahiers de l'Orient 23 (Troisieme Trimestre 1991) pp. 30-32.

${ }^{26}$ Mortimer (note 119) p. 587.

${ }^{27}$ S. Labat, Les Islamistes Algériens. Entre les urnes et les maquis, (Paris: Editions du Seuil 1995) p. 109; R. Leveau, 'Algerie. Les Pieges de l'Aide Internationale', Politique Internationale 24 (1994), p. 184 and R. Leveau, 'Crise des Etats et transitions incertaines' in R. Benhaim, Y. Courbage and R. Leveau (eds.), Le Maghreb en suspens (Paris: Les Cahiers du CERI, n. 8, 1994) p. 49.

${ }^{28}$ Leveau, 'Algerie. Les Pieges de l'Aide Internationale' (note 27) p. 184.

${ }^{29}$ Labat (note 27) p. 112.

${ }^{30}$ R. Leveau, 'Des Crises a la Guerre' in R. Leveau (ed.), L'Algerie dans la Guerre (Bruxelles: Editions Complexe 1995) pp. 20-21.

${ }^{31}$ Interview, Paris, June 2000.

${ }_{33}^{32}$ P.M. de La Gorce, 'La Dechirure', Jeune Afrique n. 1572 (13/19 Fevrier 1991) pp. 32-35.

33 J.-F. Daguzan, 'Les rapports franco-algeriens, 1962-1992. Reconciliation ou conciliation permanente?', Politique Etrangere, n. 4, (Hiver 1993-1994) pp. 885-896.

${ }^{34}$ F. Soudan, 'Mitterand contre les islamistes', Jeune Afrique, No. 1594 (17-23 Juillet, 1991), pp. 1620.

${ }^{35}$ The Soviet Union provided the bulk of weapons and training to the Algerian military.

${ }^{36}$ M. Faure, 'Washington-Islamistes. Liasons Dangereuses', L'Express, 20 Sept. 2001, pp. 88-94.

${ }^{37}$ P. Devoluy and M. Duteil, La Poudriere Algérienne (Paris: Calmann-Levy 1994) p. 123.

${ }^{38}$ de la Gorce, 'L'Algerie et les Grandes Puissances' (note 23) p. 25.

${ }^{39}$ R. Mortimer, 'Les Etats Unis face á la situation algérienne', Maghreb-Machrek n. 149 (JuilletSeptembre 1995) p. 4.

${ }^{40}$ L. Hamilton, 'A Democrat Looks at Foreign Policy', Foreign Affairs 71/3 (Summer 1992) pp. 32-51.

${ }^{41}$ A. Moussali, 'Introduction' in A. Moussali (ed.) Islamic Fundamentalism. Myths and Realities (Reading: Ithaca Press 1998) p. 7.

${ }^{42}$ L. Spector, 'Nuclear Proliferation in the Middle East', Orbis (Spring 1992) p. 191.

${ }_{43}^{4}$ A. Charef, Algérie. Le Grand Dérapage (France: Editions de l'Aube 1994) p. 99.

${ }^{44}$ Between 1986 and December 1991, the Algerian government, through the state-owned company Sonatrach, signed 13 new exploration agreements with foreign oil multinationals. A further 4 agreements were signed in the 6 months following the coup.

${ }^{45}$ R. Aliboni, "The Islamic Factor in International Economic Cooperation" in L. Guazzone (ed.), The Islamist Dilemma. The Political role of Islamist Movements in the Contemporary Arab World (Reading: Ithaca Press 1995) p. 297.

${ }^{46}$ Ibid. p. 303.

${ }^{47}$ M. Yacoubian, Algeria's struggle for democracy (New York: Council on Foreign Relations 1997) p. 18.

${ }^{48}$ J. Phillips, 'The Rising Threat of Revolutionary Islam In Algeria', Backgrounder, Washington DC, The Heritage Foundation (Nov. 1995) pp. 9-10.

${ }^{49} \mathrm{H}$. Roberts, 'Doctrinaire economics and political opportunism in the strategy of Algerian Islamism' in J. Reudy (ed.), Islamism and secularism in North Africa (New York: St. Martin's Press 1994) p. 128.

${ }^{50}$ Y. Zoubir, 'State, Civil Society and the Question of Radical Fundamentalism in Algeria' in A. Moussali (ed.), Islamic Fundamentalism Islamic Fundamentalism. Myths and Realities (Reading, Ithaca Press 1998).

${ }_{51}^{51}$ Entelis and Arone (note 22) p. 28.

${ }_{53}^{52}$ Moussali (note 41) p. 7.

${ }^{53}$ M. Stone, The Agony of Algeria (London: Hurst \& Company 1997) p. 241.

${ }^{54}$ Ibid., p. 241.

${ }^{55}$ La Jeune Afrique, No. 1525 (26 Mars-2 Avril, 1990) p. 11. 
${ }^{56}$ Hidouci (note 10) p. 172.

${ }^{57}$ The definition 'doomsday scenarios' is found in E. Eldin Shahin, Political Ascent. Contemporary Islamic Movements in North Africa (Boulder, Colorado: Westview Press 1997) p. 145.

${ }^{58}$ L. Provost, La Seconde Guerre d'Algérie: le quiproquo franco-algerien (France: Flammarion 1996) p. 101.

${ }^{59}$ Ibid. p. 101.

${ }^{60}$ C. Spencer, 'Islamism and European Reactions: The Case of Algeria' in R. Gillespie (ed.), Mediterranean Politics Vol. 2 (London: Pinter 1996) p. 131.

${ }_{62}^{61}$ Devoluy and Duteil (note 37) p. 123.

${ }^{62}$ Khennas and Mekideche (note 21) p. 76.

${ }^{63}$ H. Souaidia, La Sale Guerre, (Paris: La Découverte 2000) p. 192.

${ }^{64}$ L. Provost, 'Paris et Alger entre brouilles et complicités', Le Monde Diplomatique (Septembre 1996) pp. $4-5$.

${ }^{65}$ International marginalisation and economic sanctions are the usual punishments reserved to regimes that the West considers illegitimate. These policies may be harmful and ineffective as in Iraq or Cuba, but carry a significant symbolic value of condemnation. In the case of Algeria, the West did not even deem it necessary to make such a symbolic gesture.

${ }^{66}$ For details on the weaponry and training supplied by France, see Souaidia (note 63) p. 125. J. Ciment, Algeria. The Fundamentalist Challenge, (New York: Facts on File 1997) states that France was very much involved in the process of delivering weaponry and technology.

${ }^{67}$ Details of military spending in North African countries can be found in A. Cordesman, 'The Military Balance and Arms Sales in North Africa: 1990-1996', CSIS working papers, Washington DC, Sept. 1996.

${ }^{68}<$ http://first.sipri.org/non_first/result_milex.php?send>

${ }^{69}$ Associated France Press, Doha, June 19th 2000.

${ }^{70}$ Ibid.

${ }^{71}$ Provost, 'La Seconde Guerre'(note 58) p. 128.

${ }_{73}^{72}$ L. Martinez, La guerre civile en Algérie (Paris: Karthala 1998) pp. 276-288.

${ }_{74}^{73}$ Ibid., p. 128.

${ }^{74}$ Panel discussion held at the Center for Contemporary Arab Studies, Georgetown University, Washington DC, January 30, 1998.

${ }_{76}^{75}$ M. Allam, 'Algeri, fuga dei candidati l'elezione diventa una farsa', La Repubblica, (15 April 1999).

${ }^{76}$ F. Imposimato, 'Introduction' in Saouidia (note 63) p. 21. 